\title{
USES OF X-RAY CONTRAST MEDIA
}

Modes of

opacification

Example $\mathrm{CM}$ characteristics

\section{Luminal filling}

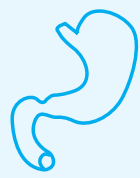

G.I. tract
No absorption;

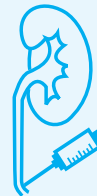

Retrograde pyelography

\section{Organ function}

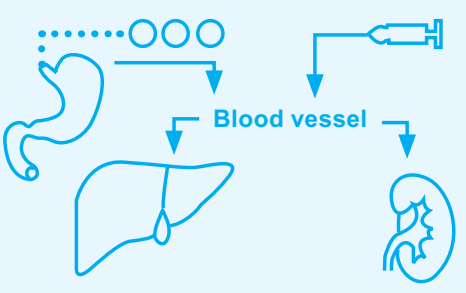

Cholegraphy

i.v. urography

\section{Parenchymal staining}

(enhancement)
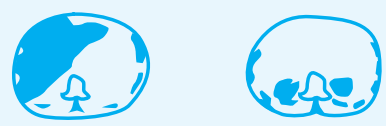

Liver CT

Kidney

\section{Angiography}

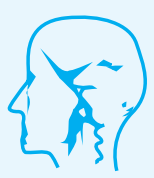

CT angiography mild or no toxicity
Organ-specific accumulation and elimination
Functional opacification exploits the physiologic function of organs, such as the kidneys and liver, namely the elimination of metabolic endproducts or exogenous substances, to visualize the organ or its drainage pathways.

The most common uses of XCM are imaging of arteries and veins and enhancement of contrasts between tissues based on differences in blood volume, perfusion, capillary permeability, and size of the interstitial space (table 12 a-c).

\section{Modes of opacification}

The identification of morphological structures is the main objective of direct luminal filling via a natural or iatrogenically (e.g., by puncture) created access; this permits the differentiation of superficial or mural changes. In addition, this mode of opacification can provide functional information, e.g., assessment of changes in tone or peristalsis in hollow passages (GI tract, ureters with retrograde filling, etc.) (fig. 19).

Fig. 19. Modes of opacification 
In cavography, the concentration of the CM administered is decisive for the degree of contrast in the radiograph. In urography and cholegraphy, on the other hand, contrast density is essentially dependent on the functional capacity of the organs being examined. Consequently, assessment of both function and morphology is possible after CM administration.

Thus, the radiological evaluation of the kidneys and turinary tract or of the hepatobiliary system reveals both morphologic and functional changes of the respective organs.

The additional functional information can provide important clues for the differential diagnosis. For example, delayed elimination of renal $\mathrm{CM}$ can be interpreted to indicate impaired glomerular filtration due to an acute or chronic disease.

Another mode of action of XCM has gained importance in computed tomography: The transit and selective accumulation of $\mathrm{CM}$ in different organs or tissues (enhancement) improve the differentiation of morphological structures, particularly between normal and pathological tissue. This allows or at least facilitates the demonstration of pathological processes and occasionally of their etiology as well. 
Fast multislice spiral CT and multi-detector CT, combined with fast image postprocessing, permits 3-dimensional imaging of the coronary arteries and other vessels after rapid i.v. injection of nonionic contrast agents. This modality can replace invasive catheter-based angiography performed for diagnostic purposes alone.

Dynamic CT during the first pass of CM provides functional information based on pharmacokinetic behavior including contrast medium arrival, washout, and distribution.

In angiography, selective opacification can be achieved by direct CM injection into the vessel of interest, followed by evaluation of CM distribution and filling patterns including gaps in opacification of the target anatomy.

This evaluation yields detailed diagnostic information regarding normal and abnormal morphology and function. 


\begin{tabular}{|c|c|c|c|c|}
\hline Mode of opacification & Method & Contrast agent & Dose (ml) & $\begin{array}{l}\text { lodine } \\
\text { concentration }\end{array}$ \\
\hline \multirow[t]{11}{*}{ Filling of the lumen } & $\begin{array}{l}\text { 1. Gastrointestinal tract } \\
\text { Orally, projection imaging }\end{array}$ & $\begin{array}{l}\mathrm{BaSO}_{4} \\
+\mathrm{CO}_{2}\end{array}$ & $\begin{array}{l}150(-400) \\
\text { variable }\end{array}$ & - \\
\hline & & Nephrotrophic CM & $50-100$ & $\begin{array}{l}370 \\
300 \\
300 / 370 \\
300 / 350 \\
300 / 350\end{array}$ \\
\hline & & Nephrotrophic CM & $500-1000$ & $10-20$ \\
\hline & & Nephrotrophic CM & $800-2000$ & $5-14$ \\
\hline & 2. Arthrography & $\begin{array}{l}\text { Nephrotrophic CM } \\
+ \text { Air }\end{array}$ & $\begin{array}{l}2-10 \\
15-35\end{array}$ & 300 \\
\hline & 3. Hysterosalpingography & Nephrotrophic CM & $5-10$ & 300 \\
\hline & 4. Fistulography & Nephrotrophic CM & variable & 300 \\
\hline & 5. Sialography & Nephrotrophic CM & $1-3$ & 300 \\
\hline & 6. PTC* ERCP $^{\star *}$ & Nephrotrophic CM & $20-40(10-40)$ & 300 \\
\hline & $\begin{array}{l}\text { 7. Retrograde Pyelography, } \\
\text { Cystography }\end{array}$ & Nephrotrophic CM & $\begin{array}{l}10-15(100-300) \\
2-300 \\
2-20 \\
10-20\end{array}$ & $\begin{array}{l}150 \\
240 / 300 / 370 \\
300\end{array}$ \\
\hline & 8. Myelography & Nephrotrophic CM & $\begin{array}{l}15 \\
5-15 \\
4-12 \\
10-15\end{array}$ & $\begin{array}{l}240-300 \\
200 / 300 \\
240 \\
240\end{array}$ \\
\hline
\end{tabular}

Table. 12a. Overview of contrast media uses

\begin{tabular}{llll} 
Mode of opacification & Method & Contrast agent & Dose (ml) \\
\cline { 2 - 4 } Organ function & 1. i.v. Urography & Nephrotrophic CM & $50-100$ \\
\cline { 2 - 4 } & 2. Inf. Urography & Nephrotrophic CM & $(250)$ \\
\cline { 2 - 4 } & 3. i.v. Cholegraphy & Liver passing CM & $20-30$ \\
\hline Parenchymal enhancement & 1. Bolusinjection & Nephrotrophic CM & $1 \mathrm{ml} / \mathrm{Kg} \mathrm{BW}$ p.r.n. more \\
\cline { 2 - 4 } & 2. Infusion & & $50-125$
\end{tabular}

Table. 12b. Overview of contrast media uses; * PTC: percutaneous transhepatic cholangiography, ** ERCP: endoscopic retrograde cholangiopancreatography 
Commercial preparations/ Trademark/

Type of contrast agent

HD preparations

Micropaque

$\mathrm{CO}_{2}$

Gastrografin

Isovist

Ultravist

Omnipaque

Imagopaque

Gastrografin $30-40 \mathrm{ml} / \mathrm{L}$

Accupaque

Isovist,

Ultravist,

Solutrast,

Omnipaque,

Imagopaque,

Imeron etc.

Ultravist etc.

Omnipaque,

Solutrast,

Imeron

Isovist etc.

Telebrix

Urografin 30\%

Ultravist

Imeron

Isovist

Iopamiron

Accupaque

Optitray

\section{Comments}

Hypotonia due to butylscopolamine ( $20 \mathrm{mg}$ i.v. or i.m.)

Faster gastrointestinal passage due to Paspertin

No barium in patients with (suspected) perforation/ suture insufficiency

For CT: fractionated administration $30 \mathrm{~min}-6 \mathrm{~h}$ before examination if necessary

\begin{tabular}{|c|c|c|}
\hline lodine concentration & $\begin{array}{l}\text { Commercial preparations/ Trademark/ } \\
\text { Type of contrast agent }\end{array}$ & Comments \\
\hline 300 & \multirow{2}{*}{$\begin{array}{l}\text { Ultravist, } \\
\text { Omnipaque } \\
\text { Solutrast etc. }\end{array}$} & \multirow{2}{*}{$\begin{array}{l}\text { Dehydrogenation is dispensable with } \\
\text { nonionic } \mathrm{CM}\end{array}$} \\
\hline $150-300$ & & \\
\hline 180 & & Injector for constant flow \\
\hline $300-370$ & \multirow{2}{*}{$\begin{array}{l}\text { Omnipaque } \\
\text { Solutrast } \\
\text { Ultravist etc. }\end{array}$} & \multirow{2}{*}{$\begin{array}{l}\text { Administration directly before the } \\
\text { examination. Scan series begins } \\
\text { approximately } 20 \text { sec after start of } \\
\text { injection }\end{array}$} \\
\hline $150-370$ & & \\
\hline
\end{tabular}




\begin{tabular}{|c|c|c|c|}
\hline Mode of imaging & Method & Contrast agent & Dose (ml) \\
\hline \multirow{9}{*}{$\begin{array}{l}\text { Conventional } \\
\text { Vasography }\end{array}$} & 1. Cardioangiography & Nephrotrophic CM & $40-60$ \\
\hline & 2. Coronary angiography & Nephrotrophic CM & $5-8$ \\
\hline & 3. Angiography & Nephrotrophic CM & 50 \\
\hline & $\begin{array}{l}\text { 4. Selective abdominal } \\
\text { angiography }\end{array}$ & Nephrotrophic CM & $5-50$ \\
\hline & $\begin{array}{l}\text { 5. Angiography of the } \\
\text { Extremities }\end{array}$ & $\begin{array}{l}\text { Nephrotrophic CM } \\
\text { nonionic }\end{array}$ & $10-70$ \\
\hline & 6. Cerebral angiography & $\begin{array}{l}\text { Nephrotrophic CM } \\
\text { nonionic }\end{array}$ & $5-10$ \\
\hline & 7. Phlebography & Nephrotrophic CM & 40 \\
\hline & 8. IA DSA & Nephrotrophic CM & $\begin{array}{l}\text { As conventional } \\
\text { angiography }\end{array}$ \\
\hline & 9. Direct lymphography & Oily & 5-10 per extreme \\
\hline
\end{tabular}

Table. 12c. Overview of contrast uses

Digital subtraction angiography (DSA) allows selective evaluation of arteries and veins without interfering background (e.g., bone) and with a very much lower $\mathrm{CM}$ concentration in the vascular regions of interest.

DSA is based on the subtraction of an image obtained immediately before CM injection from a series of images obtained with maximum $\mathrm{CM}$ filling of the target vessels.

In DSA, electronic amplification of only slight differences between the precontrast and the contrast-enhanced images results in images highlighting vessel contrast. 


\section{lodine concentration Commercial preparations/ Trademark/ Comments}

Type of contrast agent

370

Omnipaque

370

Solutrast

Ultravist etc.

300-370

300

Omnipaque

Solutrast

300

Ultravist etc.

Dose, CM concentration and

injection rate have to be the higher the better the spatial resolution, the faster the blood flow, and the larger the distance between the catheter tip and the vascular target territory is.

300

$150-300$

Omnipaque

Solutrast

Ultravist etc.

$75-300$

As conventional angiography

Less selective injection or smaller volume or lower iodine concentration is possible due to higher sensitivity of DSA

In addition, electronic data processing speeds up postprocessing of the DSA images, so that the results are immediately available.

DSA allows evaluation of larger arteries even after i.v. bolus injection of CM. In i.v. DSA and fast CT, high doses and rapid injection make particularly great demands on the tolerance of the CM. For more details see table 12 a,b and c.

Open Access This chapter is licensed under the terms of the Creative Commons Attribution 4.0 International License (http://creativecommons.org/licenses/by/4.0/), which permits use, sharing, adaptation, distribution and reproduction in any medium or format, as long as you give appropriate credit to the original author(s) and the source, provide a link to the Creative Commons license and indicate if changes were made.

The images or other third party material in this chapter are included in the chapter's Creative Commons license, unless indicated otherwise in a credit line to the material. If material is not included in the chapter's Creative Commons license and your intended use is not permitted by statutory regulation or exceeds the permitted use, you will need to obtain permission directly from the copyright holder. 